\title{
Natural and synthesized ectomycorrhizas of the alpine dwarf willow Salix herbacea
}

Accepted: 27 February 1996

\begin{abstract}
A new approach for selecting sampling sites of ectomycorrhizal roots is presented in order to describe ectomycorrhizas of Salix herbacea. Based on sporocarp mapping and statistical evaluation of the mapping data, sites for ectomycorrhizal root sampling were chosen underneath sporocarps of ectomycorrhizal Cortinarius (Myxacium) favrei, Hebeloma repandum, Laccaria montana, Entoloma alpicola, and Russula norvegica. Only in the samples beneath $C$. favrei, E. alpico$l a$, and L. montana were corresponding ectomycorrhizas predominant and therefore described. Cenococcum geophilum ectomycorrhizas occurred throughout most samples and were also described. Numerous carpophores of the five selected ectomycorrhizal fungi were sampled for isolation purposes. Pure cultures were obtained of $H$. repandum and $C$. favrei, but laboratory syntheses of ectomycorrhizas were successful only with $H$. repandum and seedlings or cuttings of $S$. herbacea.
\end{abstract}

Key words Salix herbacea · Ectomycorrhizas · Sporocarp mapping · Synthesis experiments

\section{Introduction}

Descriptions of ectomycorrhizas from alpine and arctic dwarf willows are few and mostly not very detailed (Fontana 1962; Antibus 1980; Antibus et al. 1981). This conspicuous lack of ectomycorrhizal studies in arcto-alpine habitats is due partly to difficulties with methodology. The method of Agerer (1991) for tracing mycelia from sporocarps to corresponding ectomycorrhizas is well established in lowland investigations (Agerer 1987-1990; Ingelby et al. 1990). However, in alpine

\section{F. Graf (凶) • I. Brunner}

Swiss Federal Institute for Forest,

Snow and Landscape Research WSL, Zürcherstrasse 111, CH-8903 Birmensdorf, Switzerland

Tel.: +41-1-739-24-29; Fax: +41-1-739-25-70

e-mail: frank.graf@wsl.ch studies the lack of rhizomorphs, the delicate ectomycorrhizal organs, and the soil body - a heterogeneous mixture of raw humus and gravelly stones (Graf 1994) frequently prevent an unambiguous assignment of sporocarps and ectomycorrhizas. An additional complicating factor is the number of symbiotic fungal partners associated with alpine dwarf shrubs, which is often quite high within small areas (Favre 1955; Senn-Irlet 1993; Graf 1994). Thus, a new approach is needed for investigations of ectomycorrhizas of alpine plants.

Frequent ectomycorrhizal formers are found among fungi of the "mat" type, one of Ogawa's distinguishing life forms (Ogawa 1981). In such cases, the mats are usually restricted to areas of dense growth (Read 1992). It is very likely that these below ground areas correspond to the isolated, clumped occurrence of sporocarps of one fungal taxon. Thus, there is a high probability that the ectomycorrhizas underneath the sporocarps are formed predominantly or exclusively by this one taxon.

The objective of the present study was to test a new selection procedure for sampling sites of ectomycorrhizal roots in order to describe natural Salix herbacea L. ectomycorrhizas. The sites were selected using the results of 3 years of sporocarp mapping (Graf 1994). Thus, the method of Agerer (1991) for identifying ectomycorrhizas was modified to include a restrictive selection procedure for specific ectomycorrhizal sampling sites. In addition, syntheses with pure cultures of putative ectomycorrhizal fungi and $S$. herbacea were attempted and the successful symbioses are described.

\section{Material and methods}

\section{Study site and mapping of sporocarps}

The research area is located in the eastern Swiss Alps at an elevation of 2400-2500 m in the Valley of Radönt (Canton Grisons, Switzerland) between Davos and Susch, southeast of the Flüela Pass. From 1988 to 1990, fungal sporocarps were recorded on weekly excursions during the snow-free period (June to October) 


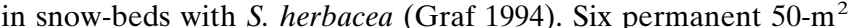
plots were installed in Salicetum herbaceae Br.-Bl. plant communities (Braun-Blanquet 1964). The shapes of the plots conformed to the most homogeneous distribution of the dwarf willow (rectangular: $2 \times 25 \mathrm{~m}, \quad 4 \times 12.5 \mathrm{~m}$; T-shaped: $2 \times 15 \mathrm{~m}+4 \times 5 \mathrm{~m}$ ). Sporocarps of all macromycetes occurring within the plots were registered and mapped. A "record" was defined as a group of sporocarps, independent of the number, of the same taxon within an area of $5 \mathrm{~cm}$ diameter.

\section{Association analysis of sporocarps}

For association analysis, only the plots with taxa of high abundance and clumped sporocarp production were considered. Thus, plot 3 with the taxa Cortinarius (Myxacium) favrei M.M. Moser ex Henderson, Hebeloma repandum Bruchet, and Laccaria montana Singer, and plot 6 with the taxa Entoloma alpicola (J. Favre) Noordel. and Russula norvegica Reid fulfilled the required criteria.

For the analysis of interspecific association, a grid of $50 \times 50 \mathrm{~cm}$ was applied to each plot to check the presence of the recorded ectomycorrhizal taxa. The results were placed in a contingency or species association table (Pielou 1977). The $2 \times 2$ table contains observed values for each of the cells $(a, b, c, d)$ from a sample of size $N$.

\begin{tabular}{cccc}
\multicolumn{5}{c}{ Species B } & \\
Species A & Present & Absent & \\
Present & $\mathrm{a}$ & $\mathrm{b}$ & $\mathrm{a}+\mathrm{b}=m$ \\
Absent & $\mathrm{c}$ & $\mathrm{d}$ & $\mathrm{c}+\mathrm{d}=n$ \\
& $\mathrm{a}+\mathrm{c}=r$ & $\mathrm{~b}+\mathrm{d}=s$ & \\
& & & \\
& & & $m+n=r+s=N$
\end{tabular}

The $\chi^{2}$-test was computed as:

$\chi^{2}=\frac{N(|a d-b c|-N / 2)^{2}}{m n r s}$

The significance levels were at $3.82(5 \%)$ and $6.64(1 \%)$ for positive (co-occurrence) and negative association (exclusion). To measure the strength of association, the Ochiai index (OI) was calculated to test relationships between species pairs without considering the number of joint absences (Ochiai 1957). This index is based on the geometric mean of the joint occurrences of the two species compared with the total occurrence of species A and B, respectively, and is calculated as

$$
O I=\frac{a}{\sqrt{(a+b)} \sqrt{(a+c)}}
$$

with 0 indicating absolute exclusion and 1 indicating absolute cooccurrence.

\section{Sampling and processing of natural ectomycorrhizas}

In the summer of 1991, five soil cores of $25 \mathrm{~cm}^{2}$ surface area and $5 \mathrm{~cm}$ depth were taken of each of the five selected ectomycorrhizal fungi, including their epigeous sporocarps. Samples were bagged, transported to the laboratory on the same day and examined for hyphal connections leading from sporocarps to fungal mantles under a Wild M8 dissecting microscope. Ectomycorrhizas were placed in water and cleaned of soil particles before being described morphologically, photographed with a Wild MPS microscope, fixed in $6 \%$ formaldehyde, and stored at $4{ }^{\circ} \mathrm{C}$ in the dark.

\section{Synthesis experiments}

Small tramal pieces of each of the five selected ectomycorrhizal fungi were cut from freshly collected sporocarps and placed in Petri dishes on modified Melin Norkrans (MMN) agar main- tained at $20^{\circ} \mathrm{C}$ in the dark (Marx and Bryan 1975). Mycelial cultures were cut into small pieces and transferred to sterilized 500$\mathrm{ml}$ Erlenmeyer flasks containing $150 \mathrm{ml}$ MMN solution (including glucose $10 \mathrm{~g} / \mathrm{l}$ and malt $3 \mathrm{~g} / \mathrm{l}$ ). After 2 months incubation, liquid mycelial cultures were homogenized with a blender. Aliquots of this solution $(50 \mathrm{ml})$ were injected into previously autoclaved 500$\mathrm{ml}$ Erlenmeyer flasks containing a Vermiculite-peat moss mixture $(200 \mathrm{ml}: 30 \mathrm{ml})$ with $150 \mathrm{ml} \mathrm{MMN}$ (including glucose $10 \mathrm{~g} / \mathrm{l}$ and malt $3 \mathrm{~g} / \mathrm{l})$. Non-sterile $1-1$ pots were similarly prepared. The fungal inocula were allowed to grow for 6 weeks prior to seedling introduction.

From 1989 to 1991, seeds of $S$. herbacea were collected in the autumn and kept at $4{ }^{\circ} \mathrm{C}$ for immediate use or at $-20^{\circ} \mathrm{C}$ for longer storage. After surface sterilization for 3-5 min with $\mathrm{H}_{2} \mathrm{O}_{2}(30 \%)$, seeds were placed on water agar in Petri dishes for germination and incubated at room temperature in daylight. After the development of the cotyledons, the seedlings were transferred to MMN agar to screen for possible contaminants (Brunner and Brunner 1990). Seedlings were introduced 2-3 weeks after germination into pre-inoculated 500-ml Erlenmeyer flasks under sterile conditions. Synthesis experiments were carried out in a growth chamber with a 16-h photoperiod (PAR $100 \mu \mathrm{mol} \cdot \mathrm{m}^{-2} \cdot \mathrm{s}^{-1}$ ) at $20^{\circ} \mathrm{C}$ and $70 \%$ humidity for $11-13$ months.

Cuttings from 6-month-old seedlings with a height of $15 \mathrm{~mm}$ and at least three leaves were used for synthesis experiments under non-sterile conditions in pre-inoculated 1-1 pots. Pots were maintained for 15 months in the greenhouse at $20 \pm 5^{\circ} \mathrm{C}$ in daylight. They were watered weekly and supplied every 4th week with $30 \mathrm{ml}$ MMN (without glucose and malt). Ectomycorrhizal rootlets were cleaned with sterile water, described morphologically, photographed, fixed in $6 \%$ formaldehyde, and stored at $4{ }^{\circ} \mathrm{C}$ in the dark.

\section{Microscopic analysis}

For microscopic analysis of natural and synthesized ectomycorrhizas, the rootlets were dehydrated in alcohol, embedded in glycolmethacrylate, sectioned longitudinally $(1.5 \mu \mathrm{m})$ with a ReichertJung 2050 microtome and stained with Giemsa for chitinoid material. Photographs were taken using a Leitz Aristoplan microscope. The microscopic description of the ectomycorrhizas mainly follows the terminology of Agerer (1991) and Ingelby et al. (1990).

\section{Results}

Sporocarp mapping, association analysis and abundance

Evaluation of the sporocarp mapping data from 19881990 produced specific spatial patterns for each of the 53 ectomycorrhizal taxa registered (Graf 1994). Clumped and isolated sporocarp production of taxonomically well-defined species was observed particularly for Cortinarius favrei, Entoloma alpicola, Hebeloma repandum, Laccaria montana, and Russula norvegica (Figs. 1, 2). Isolated clumping occurred most obviously in plot 3 for C. favrei, H. repandum, and L. montana (Fig. 1) and in plot 6 for E. alpicola and R. norvegica (Fig. 2).

The aggregation of exclusively one taxon was confirmed in various plots (Table 1); the Ochiai indices of the selected taxa were low, pointing to mutual exclusion. Interspecific association analysis confirmed significant exclusion between $C$. favrei and L. montana in 


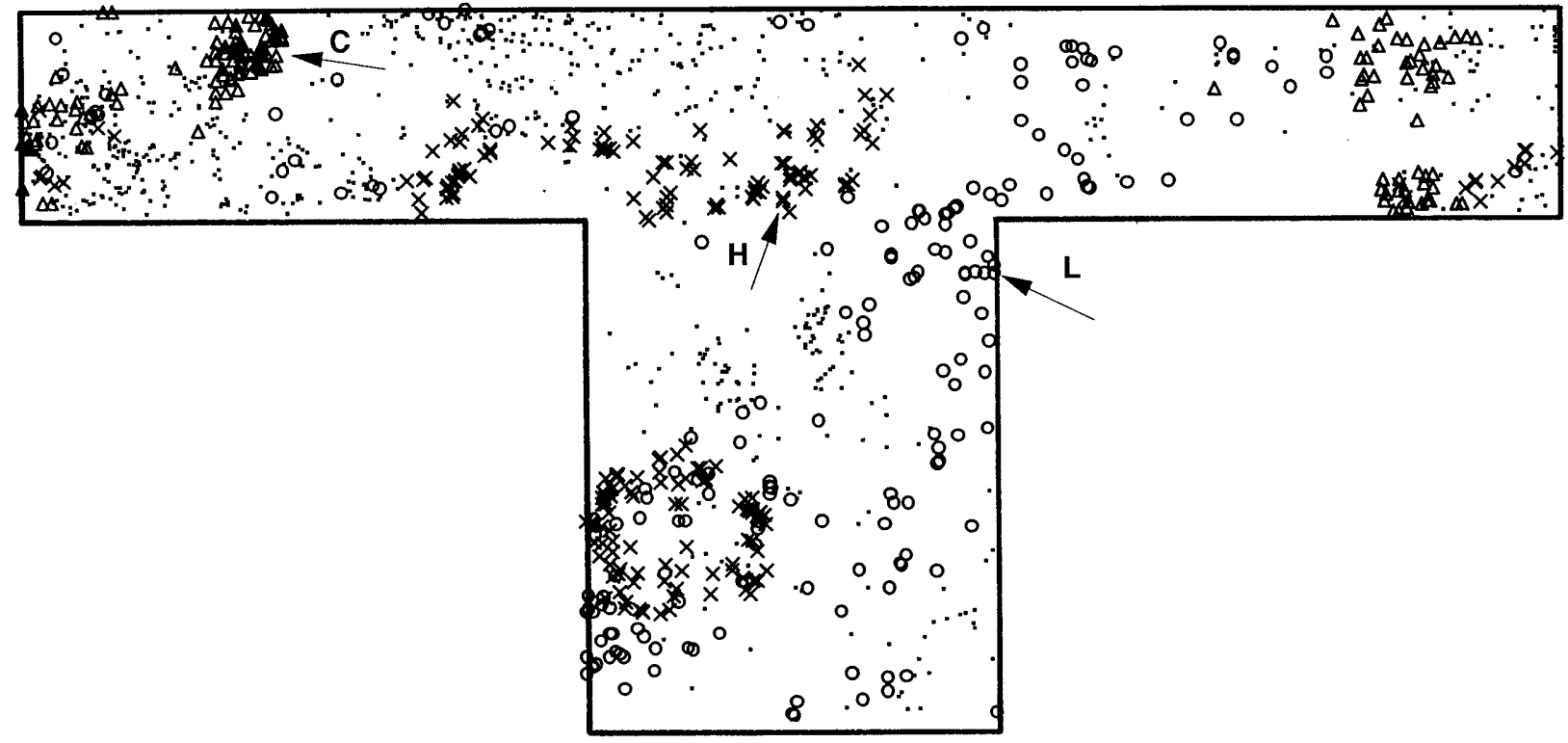

Fig. 1 Spatial distribution patterns of all recorded sporocarps of ectomycorrhizal taxa $(\bullet)$ found in 1988-1990, with special emphasis on Cortinarius favrei $(C, \triangle)$, Hebeloma repandum $(H, \times)$, and Laccaria montana $(L, \circ)$, in plot $3(2 \times 15 \mathrm{~m}+4 \times 5 \mathrm{~m})$ and the locations of ectomycorrhizal root sampling (arrows)

plot 3, and E. alpicola and R. norvegica in plot 6. However, no significant results were obtained for $C$. favrei and $H$. repandum and $H$. repandum and L. montana (Table 1). In accordance with the sporocarp mapping, association analyses, and species abundance, root samples for ectomycorrhizal investigations were taken in plot 3 (C. favrei, H. repandum, L. montana) and plot 6 (E. alpicola, $R$. norvegica).

Fig. 2 Spatial distribution patterns of all recorded sporocarps of ectomycorrhizal taxa $(\bullet)$ found in 1988-1990, with special emphasis on Entoloma alpicola $(E,+)$, and Russula norvegica $(R, \diamond)$, in plot $6(4 \times 12.5 \mathrm{~m})$ and the locations of ectomycorrhizal root sampling (arrows)
Table 1 Matrix of $\chi^{2}$-test indicating exclusion, and Ochiai index of selected ectomycorrhizal fungi in plots 3 and 6 . Ochiai index: values close to 0 indicate exclusion, values close to 1 association

\begin{tabular}{llll}
\hline Plot & $\chi^{2}$ & $\begin{array}{l}\text { Ochiai } \\
\text { index }\end{array}$ \\
\hline 3 & Cortinarius favrei/Hebeloma repandum & 0.249 & 0.20 \\
& Cortinarius favrei/Laccaria montana & $6.297^{*}$ & 0.09 \\
& Hebeloma repandum/Laccaria montana & 0.001 & 0.30 \\
6 & Russula norvegica/Entoloma alpicola & $9.622^{* *}$ & 0.02
\end{tabular}

* Significance level $5 \% ; \chi^{2}>3.82$

** Significance level $1 \% ; \chi^{2}>6.64$

\section{Natural ectomycorrhizas}

Unambiguous assignment of sporocarps and ectomycorrhizas was possible for C. favrei, E. alpicola and $L$. montana, based on the predominant occurrence of ectomycorrhizas underneath corresponding sporocarps. For $H$. repandum and $R$. norvegica, different types of ectomycorrhizas were included in each of the five samples and no obvious hyphal connections between spor-

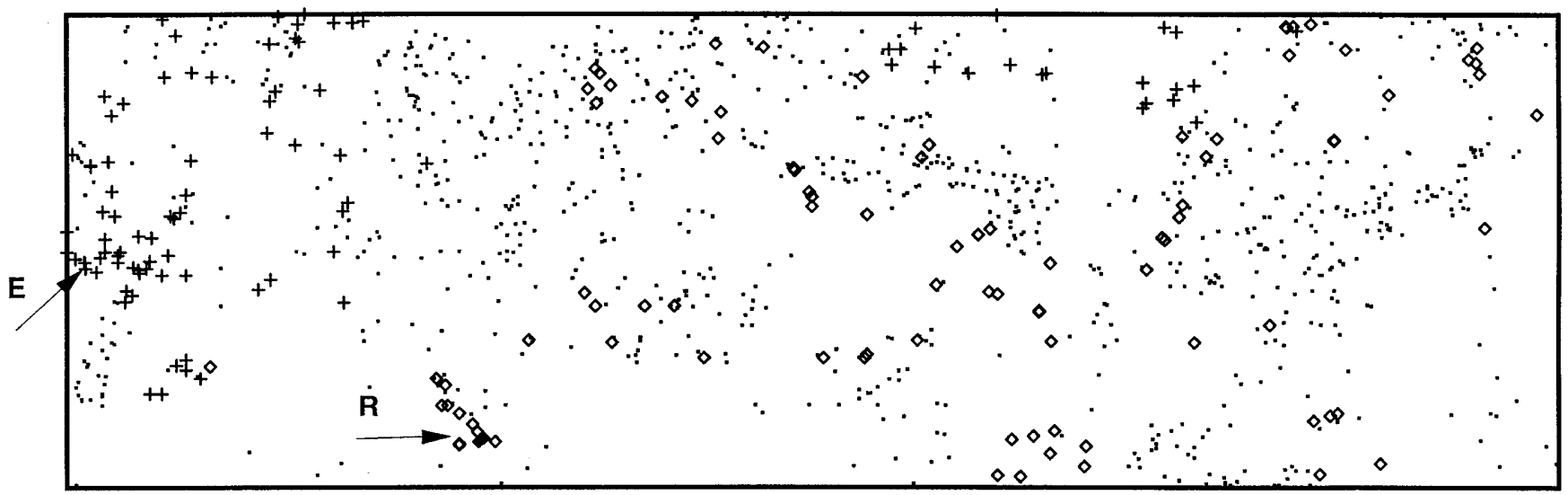



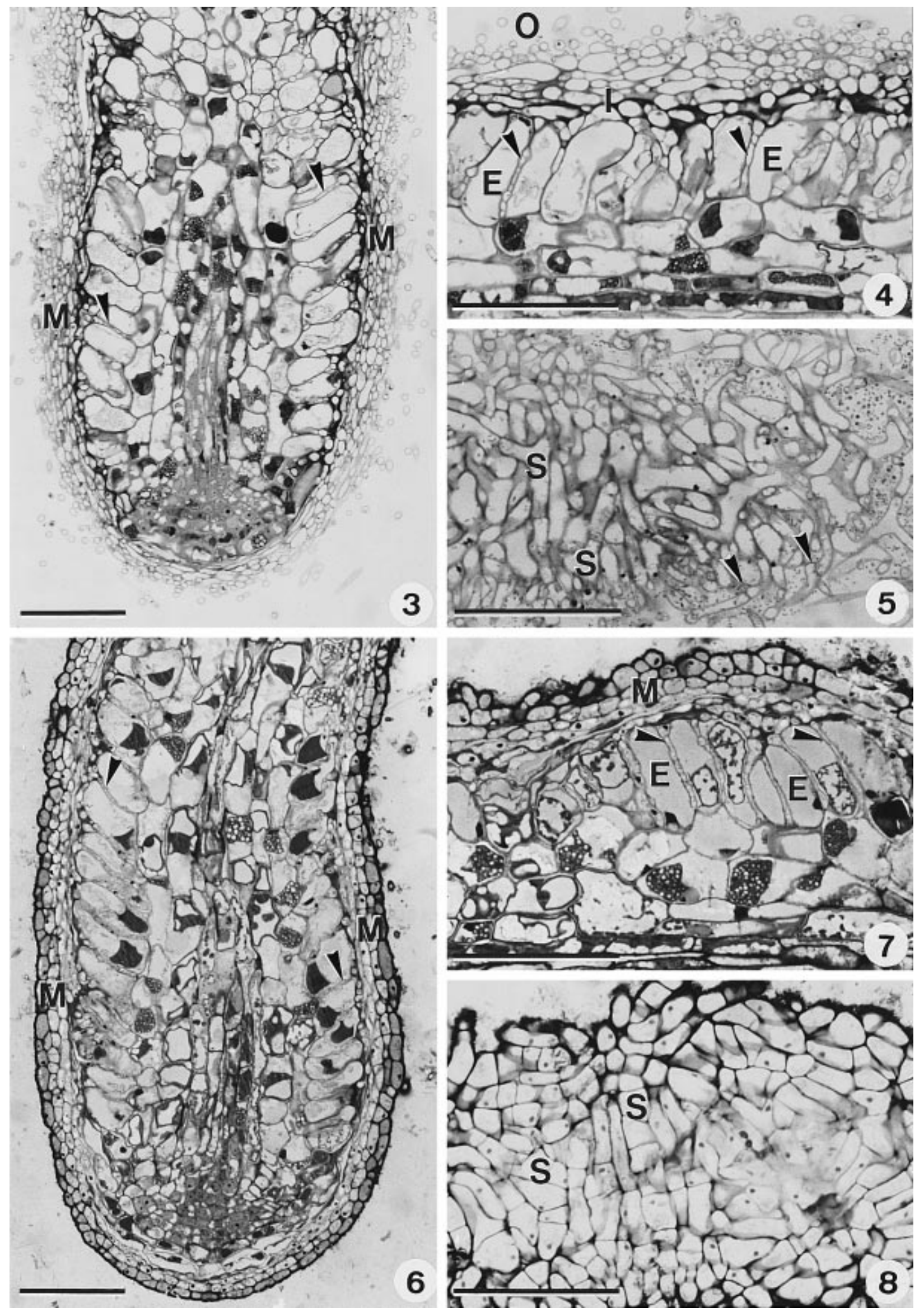
ocarps and mantles were detected. Thus, no clear assignment was possible and these two taxa were excluded from further investigations. Ectomycorrhizas formed by Cenococcum geophilum L. were noted in several soil samples and considered for further processing.

Entoloma alpicola ectomycorrhizas (Figs. 3-5) are more or less regularly monopodial, up to $0.4 \mathrm{~mm}$ in diameter and $3 \mathrm{~mm}$ long. The root tips are swollen and occasionally tortuous. The surface is villous and enveloped in white mycelium. No rhizomorphs were observed. The colour varies from brownish-yellow to light brown. The mantle is $15-35 \mu \mathrm{m}$ thick, differentiated into a prosenchymatous outer layer with branched and diverging hyphae (up to $5.0 \mu \mathrm{m}$ in diameter), and a synenchymatous inner layer with shortened, tortuous to nearly globose hyphal cells (5-25 $\mu \mathrm{m}$ long, 3-8 $\mu \mathrm{m}$ wide). The Hartig net consists of hyphal cells lined up in one, occasionally two, rows between the first layer of epidermal cells. It is uniform, and paraepidermal. Epidermal cells are distinctly radially elongated. Clamp connections are present in the prosenchymatous tissue of the outer mantle. Voucher material is deposited in Birmensdorf WSL (fg 19131).

Cenococcum geophilum ectomycorrhizas (Figs. 6-8) are unbranched, up to $0.4 \mathrm{~mm}$ in diameter, $3 \mathrm{~mm}$ long, and straight to slightly bent. The surface is smooth to delicately scrobiculate, with frequent black hyphae radiating from the mantle surface. No rhizomorphs were observed. The colour is dull black. The mantle is 15$25 \mu \mathrm{m}$ thick, two-layered, synenchymatous with shortened to isodiametric hyphal cells $(5-15 \mu \mathrm{m}$ long, 3$8 \mu \mathrm{m}$ wide). The outer layer consists of heavily thick-

Figs. 3-8 Light micrographs of natural ectomycorrhizas of Salix herbacea with Entoloma alpicola and Cenococcum geophilum; bars $50 \mu \mathrm{m}$

Fig. 3 Median longitudinal section of E. alpicola ectomycorrhiza. Fungal hyphae form a compact mantle $(M)$ around the rootlet and a Hartig net (arrowheads)

Fig. 4 Median longitudinal section of E. alpicola ectomycorrhiza. The mantle is two-layered with a prosenchymatous outer $(O)$ and a synenchymatous inner mantle $(I)$. The Hartig net is paraepidermal (arrowheads) and epidermal cells $(E)$ are radially elongated and slightly oblique

Fig. 5 Tangential longitudinal section of E. alpicola ectomycorrhiza. The inner mantle consists of a net synenchymatous tissue $(S)$. Clamp connections are present in the prosenchymatous tissue (arrowheads) of the outer mantle

Fig. 6 Median longitudinal section of $C$. geophilum ectomycorrhiza. Fungal hyphae form a compact mantle $(M)$ around the rootlet and a Hartig net (arrowheads)

Fig. 7 Median longitudinal section of $C$. geophilum ectomycorrhiza. The mantle is two-layered $(M)$ and synenchymatous, with thickened cells in the outer layer and non-thickened cells in the inner layer. The Hartig net is paraepidermal (arrowheads) and epidermal cells $(E)$ are radially elongated

Fig. 8 Tangential longitudinal section of $C$. geophilum ectomycorrhiza. The mantle consists of a synenchymatous tissue $(S)$. Clamp connections are absent ened cells, whereas the cells of the inner layer are nonthickened. The Hartig net consists of hyphal cells lined up in one, but occasionally in two rows between the first layer of epidermal cells. It is uniform, and paraepidermal. Epidermal cells are distinctly radially elongated. Clamp connections are not present. Voucher material is deposited in Birmensdorf WSL (fg 19111).

Cortinarius favrei ectomycorrhizas (Figs. 9, 10) are unbranched, up to $0.3 \mathrm{~mm}$ in diameter and $4 \mathrm{~mm}$ long. The root tips are occasionally tortuous and slightly swollen. The surface is delicately villous and enveloped in white mycelium. No rhizomorphs were observed. The colour is orange-yellow, with the tips a shade darker. The mantle is $30-40 \mu \mathrm{m}$ thick, differentiated in a prosenchymatous outer layer with more or less elongated hyphae (up to $3.0 \mu \mathrm{m}$ in diameter) and a compact synenchymatous inner layer with shortened, tortuous to nearly globos hyphal cells $(3-16 \mu \mathrm{m}$ long, 3-10 $\mu \mathrm{m}$ wide). The Hartig net consists of hyphal cells lined up in one or two rows between the first layer of epidermal cells. It is uniform and paraepidermal. Epidermal cells are distinctly radially elongated. Clamp connections are present only on the surface hyphae of the mantle. Voucher material is deposited in Birmensdorf WSL (fg 19121).

Laccaria montana ectomycorrhizas (Fig. 11) are unbranched, up to $0.3 \mathrm{~mm}$ in diameter, $5 \mathrm{~mm}$ long, and sinuous. The surface is smooth to delicately downy, and regularly covered with a white mycelium. No rhizomorphs were observed. The colour varies within different shades of brownish-orange. The mantle is $5-12 \mu \mathrm{m}$ thick, sparsely developed, one-layered, and synenchymatous (2-5 $\mu \mathrm{m}$ in diameter). The Hartig net consists of hyphal cells lined up in one row between the first layer of epidermal cells. It is paraepidermal, but not uniform. Epidermal cells are slightly radially elongated. Clamp connections are present only on the surface hyphae of the mantle. Voucher material is deposited in Birmensdorf WSL (fg 19151).

\section{Synthesized ectomycorrhiza}

Mycelial cultures obtained from sporocarp tissue were successful only with $H$. repandum and $C$. favrei. In the Erlenmeyer flasks after 11 months and in the pots after 15 months only $H$. repandum formed typical ectomycorrhizal rootlets with seedlings and cuttings. Cortinarius favrei did not develop ectomycorrhizal structures after 14-15 months of incubation in either system, although hyphae were observed on the surface of the rootlets.

Hebeloma repandum ectomycorrhizas (Figs. 12-15) are unbranched, very infrequently monopodial, up to $0.3 \mathrm{~mm}$ in diameter, $1-3 \mathrm{~mm}$ long and straight to slightly bent. The surface is smooth, occasionally slightly squamose, and covered with irregular, downy mycelium. No rhizomorphs were observed. The colour is dull brownish-yellow. Small scales are darker brownish to rusty coloured. The mantle is $20-40 \mu \mathrm{m}$ thick, differ- 

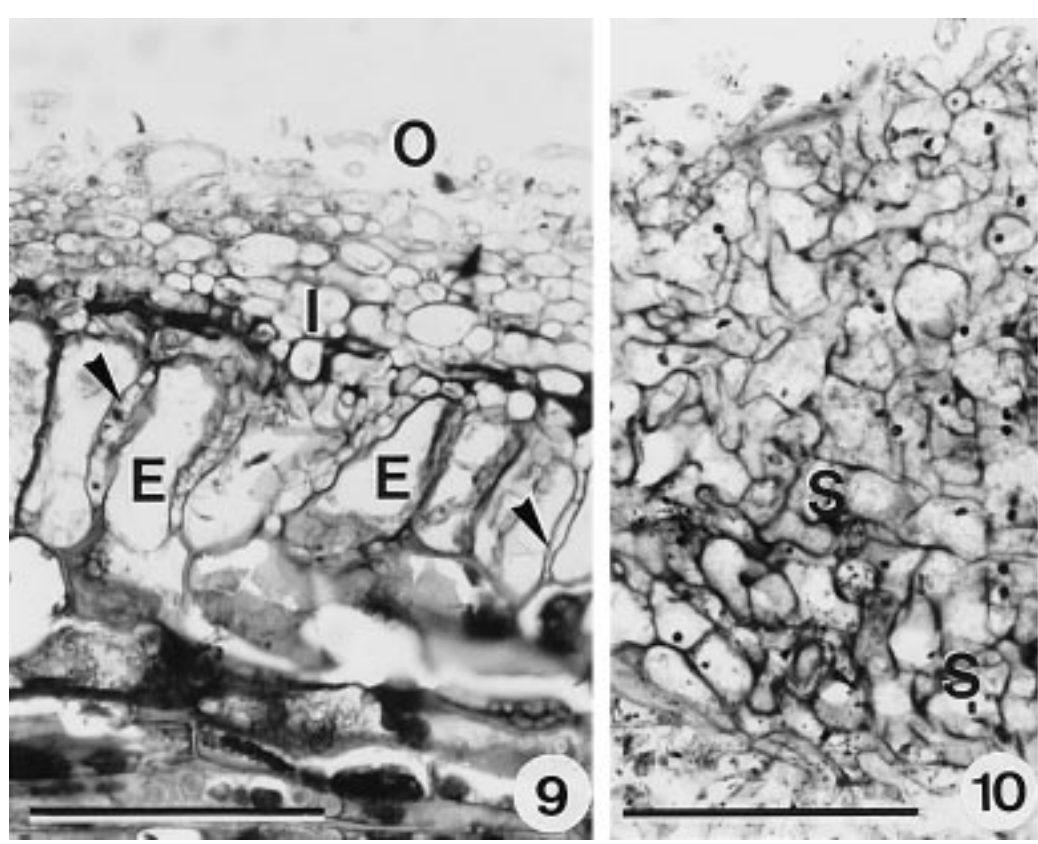

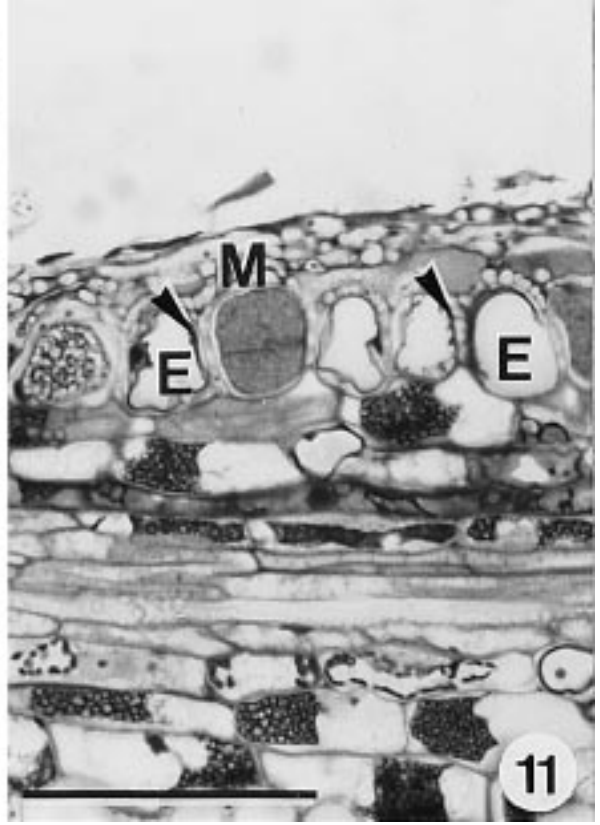

Figs. 9-11 Light micrographs of natural ectomycorrhizas of Salix herbacea with Cortinarius favrei and Laccaria montana; bars $50 \mu \mathrm{m}$

Fig. 9 Median longitudinal section of $C$. favrei ectomycorrhiza. The mantle is two-layered with a prosenchymatous outer $(O)$ and a synenchymatous inner mantle $(I)$. The Hartig net is paraepidermal (arrowheads) and epidermal cells $(E)$ are radially elongated and slightly oblique

Fig. 10 Tangential longitudinal section of $C$. favrei ectomycorrhiza. The inner mantle consists of an irregular synenchymatous tissue $(S)$

Fig. 11 Median longitudinal section of L. montana ectomycorrhi$\mathrm{za}$. The mantle is sparsely developed and one-layered $(M)$. The Hartig net is paraepidermal (arrowheads) and epidermal cells $(E)$ are only slightly radially elongated

entiated in a prosenchymatous outer layer with irregularly branched hyphae (3-5 $\mu \mathrm{m}$ in diameter) and a synenchymatous inner layer with shortened, tortuous hyphal cells (5-13 $\mu \mathrm{m}$ long, 3-6 $\mu \mathrm{m}$ wide). The Hartig net consists of hyphal cells lined up in one row (rarely two) between the first layer of epidermal cells. It is uniform, and paraepidermal. Epidermal cells are slightly radially elongated. Clamp connections are present in the prosenchymatous tissue of the outer mantle. Culture isolates of $H$. repandum are deposited in Birmensdorf WSL (50.01). Voucher material is deposited in Birmensdorf WSL (fg 19141).

\section{Discussion}

The successful identification of ectomycorrhizas with Agerer's (1991) method is very difficult with alpine dwarf willows. The ectomycorrhizas of alpine and arctic Salix are very delicate compared with those of sturdy gymnosperms and most angiosperms (Fontana 1962;
Antibus 1980; Antibus et al. 1981; Graf 1994). The fine roots with their ectomycorrhizal mantles rarely surpass $3 \mathrm{~mm}$ in length and $0.3 \mathrm{~mm}$ in diameter. The mantle surface is mostly smooth and lacks rhizomorphs or strongly developed hyphae leading to the corresponding sporocarp. Roots of the dwarf willows and their ectomycorrhizal mycelia grow through a strongly heterogeneous soil structure, unlike lowland conditions where ectomycorrhizal roots are embedded in a quite homogeneous soil body. The alpine habitat of $S$. herbacea is characterized by a thin humus layer followed by a coarse grained main root chamber with a high share of bedrock (Graf 1994). In addition, based on sporocarp mapping, ectomycorrhizal associates of $S$. herbacea are remarkably numerous, represented by up to 33 species within areas of $50 \mathrm{~m}^{2}$.

Thus, Agerer's method to locate ectomycorrhizas by tracing mycelial strands from sporocarps (Ingelby et al. 1990; Agerer 1991) is not applicable in alpine investigations as it stands. Modification of the method requires the selection of sampling sites of suitable sporocarps, which most likely occur clumped but isolated from sporocarps of other fungal taxa within homogeneous carpets of the alpine dwarf willow, and thus detailed sporocarp mapping and statistical evaluation. The modification described here is based on Ogawa's description (Ogawa 1981) of a fungal growth form classified as "irregular mycelial mat" (distinct from "fairy ring" and "dispersed colony" types). Sporocarps (and ectomycorrhizas) fruit within this area of concentrated mycelial mats. Representatives of this life type in alpine dwarf willows are most likely members of the genus Cortinarius, and probably also Entoloma and Laccaria (Ogawa 1981; Agerer 1987; Read 1992). Taxa of Russula and Hebeloma rather form mycelia of the dispersed colony type, which agrees with the observation that root samples underneath sporocarps of $H$. repandum 


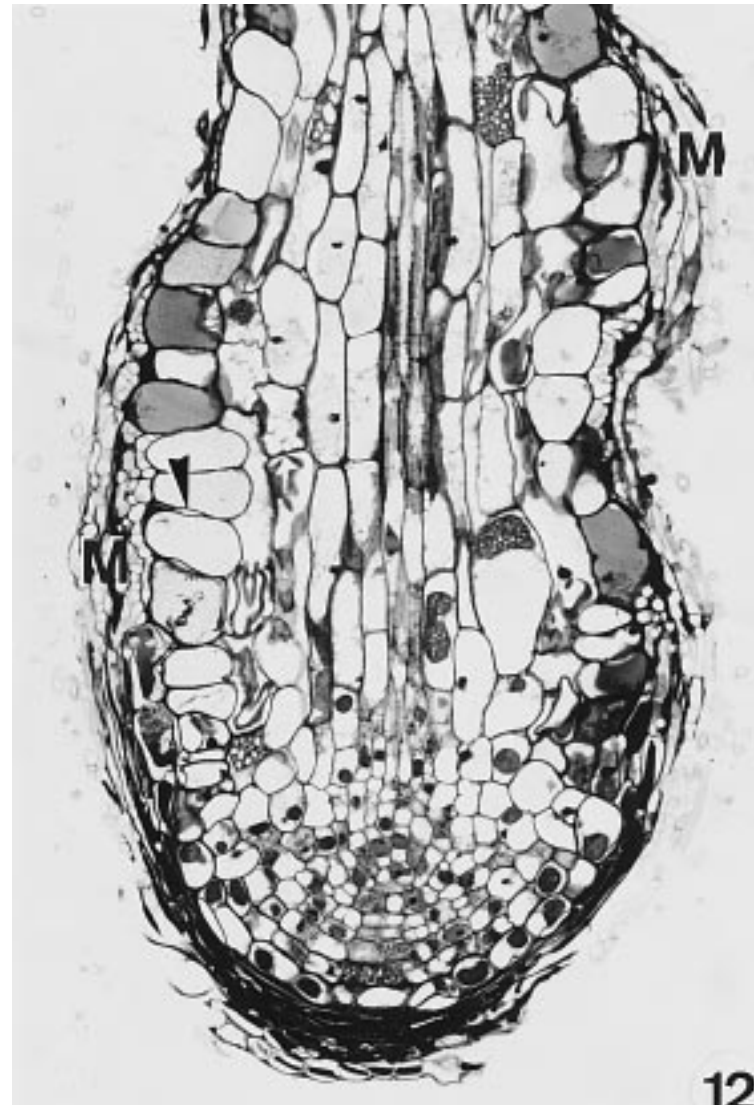

12

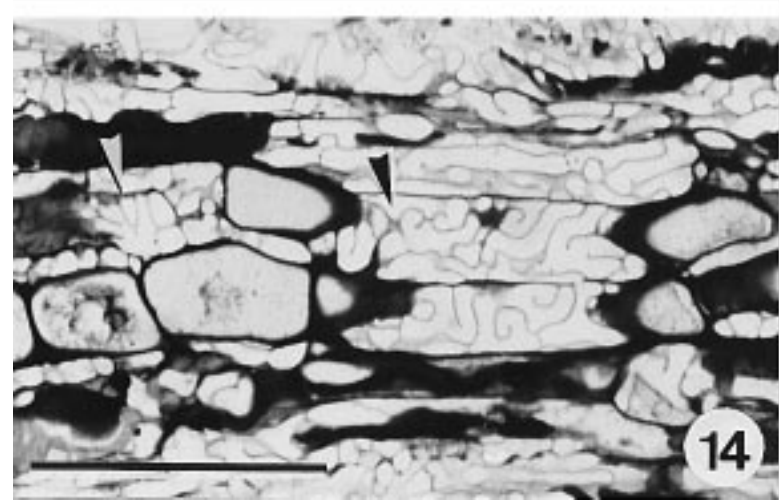

Figs. 12-15 Light micrographs of synthesizes ectomycorrhizas of Salix herbacea with Hebeloma repandum; bars $50 \mu \mathrm{m}$

Fig. 12 Median longitudinal section. Fungal hyphae form a mantle $(M)$ around the rootlet and a Hartig net (arrowhead)

Fig. 13 Median longitudinal section. The mantle is two-layered with a prosenchymatous outer $(O)$ and a synenchymatous inner mantle $(I)$. The Hartig net is paraepidermal (arrowheads) and epidermal cells $(E)$ are slightly radially elongated

Fig. 14 Tangential longitudinal section of the Hartig net showing the multibranched finger-like hyphae (arrowheads)

Fig. 15 Tangential longitudinal section. The inner mantle consists of a net synenchymatous tissue $(S)$. Clamp connections (arrowheads) are present in the prosenchymatous tissue $(P)$ of the outer mantle
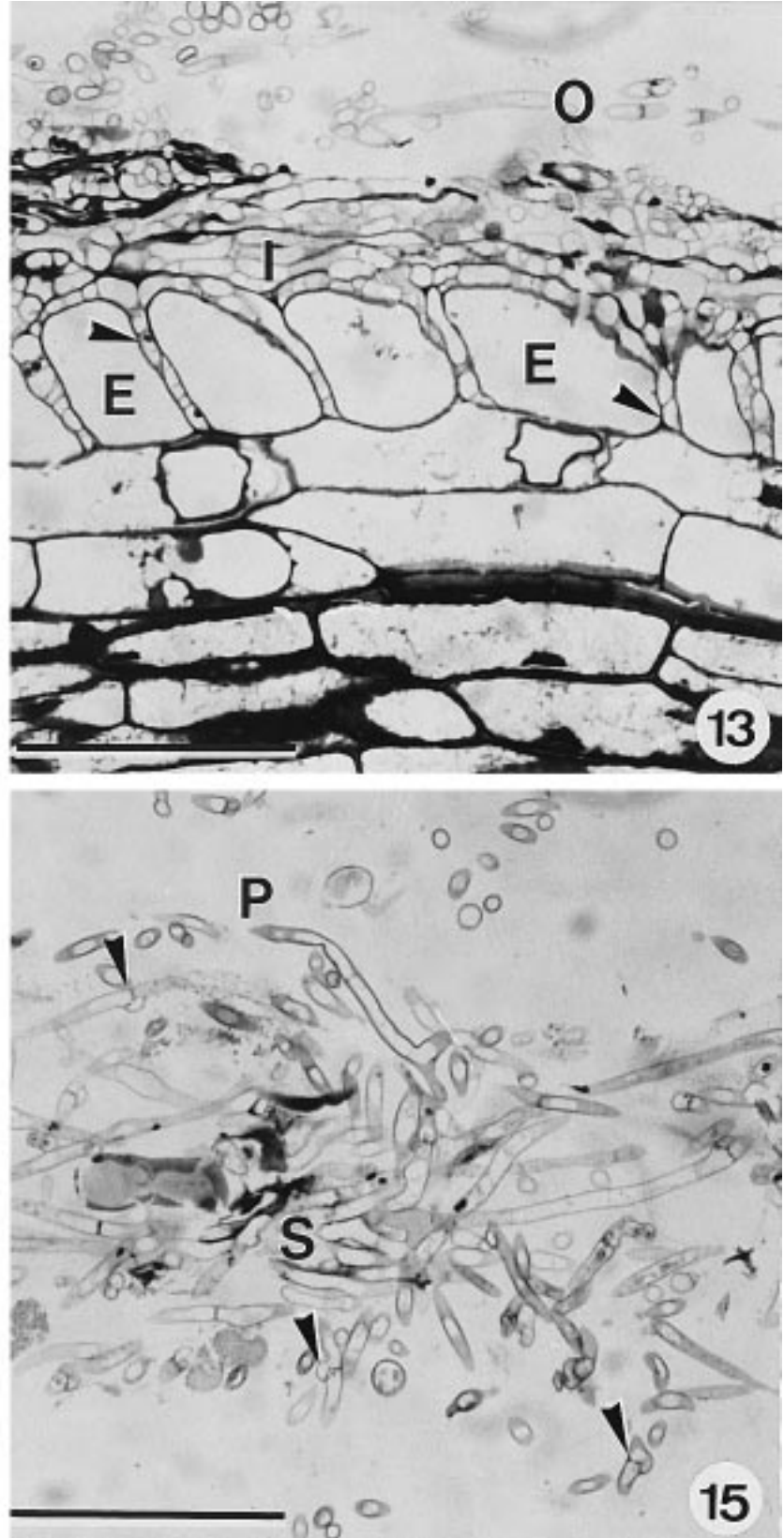

and $R$. norvegica included various ectomycorrhizal types, and that interspecific association analyses between these two taxa were not significant (Graf 1994).

So far, no data are available from arcto-alpine zones which allow correlation of above ground sporocarp pattern and below ground ectomycorrhiza distribution, and results from coniferous forests do not provide data of this type (Jansen and De Nie 1988; Danielson and Pruden 1989; Taylor and Alexander 1990; Mehmann et al. 1995). However, results of Laiho (1970), Agerer (1990), and Dahlberg and Stenlid (1994) indicate a correlation between above and below ground for certain species, which provides an incentive to test the new approach. Biochemical and molecular biological analyses, such as the PCR method, are promising tools to answer specific questions in the near future. 
Descriptions and drawings of ectomycorrhizas found on alpine willow (S. reticulata L., S. serpyllifolia Scop.) given by Fontana (1962) following the classification of Dominik (1959) distinguish four different types of ectomycorrhizas (including $C$. geophilum) without providing further identification of the fungal partners; a weakly developed or epidermal Hartig net is common to all four types described. Antibus (1980) detected two dominant morphological types in association with an arctic willow ( $S$. rotundifolia) in Alaska. One was described as having a smooth, reddish-white mantle and the other as having a smooth, white mantle. Both types had Hartig nets reaching the innermost cortical layer, indicating possible ectomycorrhizal association with plants other than Salix since angiosperms have paraepidermal Hartig nets (Godbout and Fortin 1985). A third, black ectomycorrhiza type formed by $C$. geophilum with a Hartig net restricted to the epidermal layer is similar to that reported in the present study.

The first successful synthesis experiments with a dwarf willow (S. rotundifolia) were carried out by Antibus et al. (1981) with H. pusillum J. Lange, E. sericeum (Bull.) Quél., and C. geophilum. Here, the morphology of the $H$. pusillum type was almost identical with that synthesized between $S$. herbacea and $H$. repandum in the present study, or $H$. crustuliniforme (Bull. ex St. Amans) Quél. (unpublished data), suggesting that Salix-Hebeloma types are similar. In addition, synthesized ectomycorrhizas of $C$. geophilum or E. sericeum with $S$. rotundifolia (Antibus et al. 1981) were almost identical with natural ectomycorrhizas observed between $S$. herbacea and C. geophilum or E. alpicola.

So far, no adequate material is available for the comparison of natural ectomycorrhizas of $S$. herbacea with C. favrei and L. montana. Ectomycorrhizas of Cortinarius and Laccaria synthesized with Populus tremuloides Michx. (Godbout and Fortin 1985) show some similarity to the $S$. herbacea symbiosis with the corresponding fungal taxa in the present study. Natural, as well as synthesized, ectomycorrhizas of arcto-alpine Dryas species are not comparable to those of arctoalpine dwarf Salix because of their cortical and epidermal Hartig nets, respectively (Debaud et al. 1981; Melville et al. 1987a,b; Melville et al. 1988). However, the mantle structure of the ectomycorrhizas between $\mathrm{He}$ beloma and Dryas are similar to each other and to those of Salix.

The verification of ectomycorrhizal relationships between $S$. herbacea and C. favrei, E. alpicola, L. montana and the successful synthesis of ectomycorrhizas between this dwarf willow and $H$. repandum are the first data reported for this plant and its ectomycorrhizal structures.

Acknowledgements We thank E. Horak and J. C. Debaud for information about taxonomy and alpine ectomycorrhizas. We also express our gratitude to B. Schneider for technical assistance, S. Egli for laboratory support, and C. Lanphear-Cook and J. Cook for carefully reading an earlier version of this manuscript and correcting the English.

\section{References}

Agerer R (1987-1990) Colour atlas of ectomycorrhizae (1st-4th edn). Einhorn, Schwäbisch Gmünd, Germany

Agerer R (1987) The ecologically crucial question of ectomycorrhizas: how to make rhizomorphs. In: Sylvia DM, Hung LL, Graham JH (eds) Proceedings of the 7th North American Conference on Mycorrhizae, Gainesville, Fla, pp 184-185

Agerer R (1990) Gibt es eine Korrelation zwischen Anzahl der Ektomykorrhizen und Häufigkeit ihrer Fruchtkörper? Z Mykol 56:155-158

Agerer R (1991) Characterization of ectomycorrhiza. In: Norris NR, Read DJ, Varma AK (eds) Methods in microbiology. Academic Press, London, pp 25-73

Antibus RK (1980) Mechanisms of acclimation to lowered growth temperatures in isolates of arctic and temperate ectomycorrhizal fungi. PhD thesis, Virginia Polytechnic Institute and State University, Blacksburg, USA

Antibus RK, Croxdale JE, Miller OK, Linkins AE (1981) Ectomycorrhizal fungi of Salix rotundifolia. III. Resynthesized mycorrhizal complexes and their surface phosphatase activities. Can J Bot 59:2458-2465

Braun-Blanquet J (1964) Pflanzensoziologie; Grundzüge der Vegetationskunde. Springer, Vienna

Brunner F, Brunner I (1990) A new method to produce numerous uncontaminated alder seedlings. Eur J For Pathol 20:430435

Dahlberg A, Stenlid J (1994) Size, distribution and biomass of genets in populations of Suillus bovinus revealed by somatic incompatibility. New Phytol 115:487-493

Danielson RM, Pruden M (1989) The ectomycorrhizal status of urban spruce. Mycologia 81:335-341

Debaud JC, Pepin R, Bruchet C (1981) Etude des ectomycorhizes de Dryas octopetala. Obtention de synthèses mycorhiziennes et de carpophores d'Hebeloma alpinum et H. marginatulum. Can J Bot 59:1014-1020

Dominik T (1959) Synopsis of a new classification of the ectotrophic mycorrhizae established on morphological and anatomical characteristics. Mycopathol Mycol Appl 11:359-367

Favre J (1955) Les champignons de la zone alpine du Parc National Suisse. Ergeb Wiss Unter Schweiz Nationalparkes 5:1212

Fontana A (1962) Ricerche sulle micorrhize del genere Salix. Allionia $8: 67-85$

Godbout C, Fortin JA (1985) Synthesized ectomycorrhizas of aspen: fungal genus level of structural characterization. Can J Bot 63:252-262

Graf F (1994) Ecology and sociology of macromycetes in snowbeds with Salix herbacea L. in the alpine Valley of Radönt (Grisons, Switzerland). Diss Bot 235:1-242

Ingelby K, Mason PA, Last FT, Fleming LV (1990) Identification of ectomycorrhizas. ITE Res Pub 5:1-112

Jansen AE, De Nie HW (1988) Relations between mycorrhizas and fruitbodies of mycorrhizal fungi in Douglas fir plantations in The Netherlands. Acta Bot Neerl 37:243-249

Laiho O (1970) Paxillus involutus as a mycorrhizal symbiont on forest trees. Acta For Fenn 106:1-73

Marx DH, Bryan WC (1975) Growth and ectomycorrhizal development of lobolly pine seedlings in fumigated soil infested with the fungal symbiont Pisolithus tinctorius. For Sci 21:245254

Mehmann B, Egli S, Braus GH, Brunner I (1995) Coincidence between molecularly or morphologically classified ectomycorrhizal morphotypes and fruitbodies in a spruce forest. In: Stocchi V, Bonfante P, Nuti M (eds) Biotechnology of ectomycorrhizae. Plenum Press, New York, pp 41-52

Melville LH, Massicotte HB, Peterson RL (1987a) Ontogeny of ectomycorrhiza synthesized between Dryas integrifolia and Hebeloma cylindrosporum. Bot Gaz 148:332-341 
Melville LH, Massicotte HB, Peterson RL (1987b) Morphological variation in developing ectomycorrhizas of Dryas integrifolia and five fungal species. Scanning Electron Microsc 1:14551464

Melville LH, Massicotte HB, Ackerley CA, Peterson RL (1988) An ultrastructural study of modifications in Dryas integrifolia and Hebeloma cylindrosporum during ectomycorrhiza formation. Bot Gaz 149:408-418

Ochiai A (1957) Zoogeographic studies on the soleoid fish found in Japan and its neighbouring regions. Bull Jap Soc Sci Fish $22: 526-530$

Ogawa M (1981) Ecological characters of ectomycorrhizal fungi and their mycorrhizae. In: Proceedings of the IUFRO World Congress XVII. Japanese IUFRO Congress Comittee, pp 8995
Pielou EC (1977) An introduction to mathematical ecology (2nd edn). Wiley, New York

Read DJ (1992) The mycorrhizal mycelium. In: Allen MJ (ed) Mycorrhizal functioning. Chapman \& Hall, New York, pp $102-133$

Senn-Irlet B (1993) The mycoflora of alpine mire communities rich in Salix. Bibl Mycol 150:235-249

Taylor AFS, Alexander IJ (1990) Demography and population dynamics of ectomycorrhizas of Sitka spruce fertilized with N. Agric Ecosyst Environ 28:493-496 